ARTUR JAZDON

Uniwersytet im. Adama Mickiewicza w Poznaniu, Biblioteka Uniwersytecka

\title{
Towarzystwo Przyjaciół Biblioteki Uniwersyteckiej w Poznaniu w latach 1929-1939
}

Streszczenie. Jednym z podstawowych zadań Biblioteki Uniwersyteckiej powołanej na podstawie zbiorów Kaiser-Wilhelm-Bibliothek było dążenie do ich polonizacji i dostosowywania do potrzeb rozwijającego się uniwersytetu. Przeznaczane na ten cel środki finansowe były niewystarczające, co więcej, w związku z kryzysem finansów państwa były systematycznie zmniejszane. Dokładano więc wielu starań, by pozyskiwać wpływy beznakładowe - egzemplarze obowiązkowe i dary. Od roku 1923 rozpoczęto starania o powołanie Towarzystwa Przyjaciół Biblioteki Uniwersyteckiej, które ostatecznie powstało w 1929 roku. Jego celem było skupienie osób z różnych grup społecznych, zainteresowanych książką i chcących działać na rzecz wspierania Biblioteki. Zamiarem Towarzystwa było zbieranie środków finansowych i kupowanie za nie niezbędnych materiałów bibliotecznych. Realizowano je aż do wybuchu II wojny światowej, choć w stopniu mniejszym niż zapewne oczekiwano. Natomiast Towarzystwo, zrzeszające może niezbyt szerokie, ale elitarne grono członków, położyło duże zasługi w zakresie lobbowania na rzecz Biblioteki, czego efektem stało się nagłaśnianie jej problemów, docieranie do różnych kręgów decyzyjnych i osób prywatnych. Dzięki temu zbiory Biblioteki w latach 1929-1939 nasycone zostały dużą liczbą cennych darów, co służyło realizacji wspomnianych podstawowych zadań w zakresie kształtowania zasobów.

SŁowa KLuczowe: Uniwersytet Poznański, Biblioteka Uniwersytecka w Poznaniu, polityka gromadzenia zbiorów, promocja książki i czytelnictwa.

$\mathrm{Na}$ dziewiątej stronie sprawozdania dyrekcji Biblioteki Uniwersyteckiej w Poznaniu za rok akademicki 1928/29 (od 1 września 1928 do 31 sierpnia 1929) ${ }^{1}$ zanotowano, jako warty wskazania, fakt powołania

${ }^{1}$ Sprawozdanie Dyrekcji Biblioteki Uniwersyteckiej w Poznaniu za rok akademicki 1928/29 (od 1 września 1928 do 31 sierpnia 1929), Poznań 1929, rkps BU 104887 IV, s. 9. 
do życia 2 maja 1929 roku Towarzystwa Przyjaciół Biblioteki Uniwersyteckiej, które miało powstać - jak zapisano - w odpowiedzi na ogłoszony w miejscowej prasie apel przedstawiający potrzeby księgozbioru ${ }^{2}$. Wspomniana odezwa była jednak jednym z ostatnich etapów kilkuletnich starań o zawiązanie Towarzystwa, a nie tylko odpowiedzią na zamieszczony w prasie apel. Realizację inicjatywy można łączyć z objęciem 1 września 1927 roku funkcji dyrektora przez doc. dr. Stefana Vrtela-Wierczyńskiego, dotychczasowego kustosza Biblioteki Uniwersyteckiej we Lwowie. $\mathrm{Z}$ jego osobą wiązano duże nadzieje, co znalazło odbicie $w$ wypowiedzi prorektora prof. dr. Jana Grochmalickiego wygłoszonej w czasie rozpoczęcia roku akademickiego 1927/28. Stwierdził on, że dotychczas kierownictwo Biblioteki „polegało na prowizorium”, a objęcie funkcji przez Vrtela-Wierczyńskiego ma doniosłe znaczenie dla stworzenia z Biblioteki sprawnego i zasobnego warsztatu naukowego, odpowiadającego nowoczesnym potrzebom uczelni ${ }^{3}$. Od tego okresu można faktycznie obserwować wiele różnorodnych inicjatyw dotyczących każdego praktycznie aspektu merytorycznego i organizacyjnego Biblioteki i jej działalności. Trzeba jednak stwierdzić, że powołanie do życia Towarzystwa nie było pionierską inicjatywą na teranie Polski i, co więcej, nie było autorskim pomysłem nowego dyrektora Biblioteki Uniwersyteckiej w Poznaniu.

Pierwsze ślady działań $w$ tym kierunku odnajdujemy już bowiem w roku 1923. Wówczas to, na posiedzeniu 25 października, Komisja Biblioteczna poleciła ks. dr. Henrykowi Likowskiemu, zastępującemu nieobecnego wówczas dyrektora Edwarda Kuntzego, podjęcie wstępnych kroków w celu utworzenia Towarzystwa Przyjaciół Biblioteki Uniwersyteckiej. . Można jednak założyć, że rozmowy na ten temat toczono wcześniej, bo ks. Likowski list w tej sprawie skierował do dyrektora Biblioteki Jagiellońskiej, prof. Franciszka Papee już 1 października 1923 roku. Zaczynał się on zdaniem: „Trudne położenie Bibljoteki naszej w Poznaniu, wyczerpanie dotacji na pomoce naukowe, a przedewszystkim nieszczególne widoki dotacyjne na przyszłość najbliższa, zniewalają nas do tego, by śladem Bibljoteki Jagiellońskiej założyć w Poznaniu «Towarzystwo Przyjaciół Biblioteki Uniwersyteckiej»". W dalszej części listu ks. Likowski prosił o przysłanie egzemplarza ustawy towarzystwa krakowskiego, wzoru odezwy ogłoszonej w gazetach, a także łaskawe udzielenie kilku

2 Zob. „Kurier Poznański”, nr 195 z 26.04.1929, s. 8.

${ }^{3}$ Kronika Uniwersytetu Poznańskiego za rok szkolny 1927/28 za rektoratu prof. dr. Jana Grochmalickiego, Poznań 1928, s. 12.

4 Archiwum BU, Komisja Biblioteczna od 14.10.1920 do 18.03.1932, sygn. 21, k. 144. 
praktycznych wskazówek płynących z doświadczeń krakowskich, z których można by skorzystać w Poznaniu ${ }^{5}$. Dokument opatrzono dwiema adnotacjami - o załatwieniu sprawy i poleceniem skierowanym do sekretariatu: „utworzyć akta: «Tow. Przyjaciół Biblioteki Uniwersyteckiej»”. Bardzo szybko, bo już 5 października na list odpowiedział Józef Grycz, ówczesny kierownik Czytelni Ogólnej Biblioteki Jagiellońskiej, który z żalem stwierdzał, że pierwszych próśb nie może spełnić, bo statut i odezwa są dopiero przygotowywane. Przedstawił natomiast kilka uwag na temat dotychczasowych działań krakowskich, wierząc, że mogą być przydatne i w Poznaniu. Informował, że należy przygotować zaproszenie na zebranie dyskusyjne, w którym to tekście zarysowuje się ogólnie potrzebę, cel i rację bytu towarzystwa. Winno być ono podpisane przez kilka, w nawiasie uściślał - 10 wpływowych osób, i wysłane imiennie do reprezentantów „z najszerszych sfer interesujących się dobrem Biblioteki”. Na zebraniu należy wybrać Zarząd Tymczasowy, który wypracowuje statut i odezwę, po zatwierdzeniu rozsyłaną do redakcji gazet. Precyzyjnie podawał dalej, że celem towarzystwa krakowskiego jest śledzenie potrzeb biblioteki oraz popieranie jej interesów i rozwój, co zamierza się osiągnąć przez:

- budowanie zainteresowania problematyką biblioteki w jak „najszerszych warstwach",

- wynajdywanie, wyjednywanie i nabywanie odpowiednich dla celów biblioteki druków i rękopisów,

- wyjednywanie i zbieranie darów i środków pieniężnych,

- podejmowanie "przedsiębiorstw dla przysporzenia funduszy".

Uzyskane fundusze zamierzano przeznaczać na cele administracyjne, pokrywanie kosztów publikacji, zakup druków i rękopisów oraz ewentualnie inne zadania. Te punkty według Grycza winny stanowić osnowę statutu' ${ }^{6}$ Mimo otrzymania tak dokładnych instrukcji na posiedzeniu 26 listopada 1923 roku Komisja Biblioteczna postanowiła z pomysłu założenia towarzystwa tymczasowo zrezygnować z powodu innych realizowanych prac ${ }^{7}$. Przytoczyłem dość dokładnie wskazówki Grycza, bo po kilku latach odnajdziemy je w dokumentach poznańskich.

Sytuacja nie zmieniała się na lepsze i zapewne problem wspierania Biblioteki był znany i być może nawet dyskutowany w kręgach naukowców czy miłośników ksiąg. Zdaje się o tym świadczyć m.in. pismo z 8 maja

${ }^{5}$ List Henryka Likowskiego z 1.10.1923 do Franciszka Papee. Archiwum BU w Poznaniu, sygn. 35, Różne z lat 1904-1928, s. 218.

${ }^{6}$ Ibidem, list Józefa Grycza z 5.10.1923, s. 219-220.

7 Archiwum BU, Komisja Biblioteczna od 14.10.1920 do 18.03.1932, sygn. 21, k. 148. 
1928 roku, skierowane do dyrektora Biblioteki przez mieszkańca Poznania Wacława Wichlińskiego. Ośmielał się on, jak na wstępie zaznaczał, zaproponować projekt „doraźnej jednorazowej pomocy, która miałaby być udzielona Bibliotece Uniwersyteckiej przez społeczeństwo i instytucje poznańskie drogą dobrowolnych składek"8. Stwierdzał dalej, że zła sytuacja finansowa Biblioteki jest mu znana, w tym określane przez niego na kwotę 70000 zł zaległości względem księgarń i wydawców krajowych oraz zagranicznych. Podkreślał, że Biblioteka jako młoda instytucja cierpi na odczuwany szczególnie przez studentów brak wielu dzieł naukowych, które należałoby uzupełnić. Nie był w stanie określić dokładnie sumy potrzebnej na ten cel, ale szacował ją na kwotę 100000 zł. Pisał dalej: „Chcąc, że się tak wyrażę postawić Bibliotekę na nogi potrzebna jest suma 250000 zł”. W związku z tym po dokładnym rozważeniu przedstawił projekt pozyskania potrzebnej kwoty. Zaproponował jej zebranie przez następujące składki ofiarodawców: 5000 majątków po 30 zł, co miało dać 150000 zł; 500 firm po 50 zł, dające 25000 zł; 50 instytucji po 500 zł, co dawało również 25000 zł; 5000 osób prywatnych po 10 zł, dające kolejne 50000 zł. Zakładał, że są to liczby przybliżone i zbiórka może przynieść nawet 500000 zł. To, ile uda się ostatecznie uzyskać, zależy - jak pisał - od umiejętnego pokierowania sprawą. Tu konkretyzował swą ofertę: „Ponieważ znam społeczeństwo i umiem przemawiać do jego uczuć, podejmę się mój projekt zrealizować, bez narażania Biblioteki Uniwersyteckiej, jako instytucji państwowej; pokierowałbym tą sprawą tak, by wyglądała na samorzutny apel młodzieży akademickiej do społeczeństwa" ${ }^{\prime \prime}$. Mimo że list kończył stwierdzeniem, że opracował również plan techniczny, który jest gotów przedstawić, a jeśli zajdzie potrzeba, uzupełnić list stosownymi referencjami, odpowiedź udzielona 28 czerwca tego roku była krótka. Dyrektor Vrtel-Wierczyński informował, że Komisja Biblioteczna nie zgodziła się na przyjęcie przedstawionej propozycji ${ }^{10}$. Jednakże nie można wykluczyć, że jej złożenie i dyskusja nad nią wpłynęły na przyspieszenie decyzji o podjęciu stosownych działań. Zdaje się to potwierdzać dyskusja odbyta na posiedzeniu 18 czerwca. Dotyczyła ona pozyskiwania nadzwyczajnych funduszy na pomnażanie i wzbogacanie zbiorów w kontekście możliwości nabycia za 50000 zł z Biblioteki Baworowskich dubletów rzadkich druków staropolskich z XVI-XVIII wieku. Postanowiono wówczas nie oddawać "tej sprawy w ręce młodzieży” - widzimy tu nawiązanie do propozycji Wichlińskiego - natomiast zwrócić się za

\footnotetext{
${ }^{8}$ Ibidem, list Wacława Wichlińskiego z 8.05.1928, s. 362-363.

${ }^{9}$ Ibidem, s. 364.

${ }^{10}$ Ibidem, list Stefana Vrtela-Wierczyńskiego z 28.06.1928, s. 364.
} 
pośrednictwem Towarzystwa Przyjaciół Uniwersytetu z gorącym apelem o udzielenie pomocy do społeczeństwa. W tym właśnie momencie dyskusji dyrektor Vrtel-Wierczyński zaproponował zawiązanie na wzór działającego w Krakowie Towarzystwa Przyjaciół Biblioteki Uniwersyteckiej ${ }^{11}$.

Już po powołaniu Towarzystwa, podkreślając wagę tego faktu, prof. dr Edward Lubicz-Niezabitowski wskazał, że powstało ono, by starać się o fundusze na zakup książek i o rozszerzenie dotychczasowych pomieszczeń ${ }^{12}$. To drugie zadanie $\mathrm{w}$ wymiarze finansowym zapewne nie było możliwe do realizacji skromnymi siłami Towarzystwa. W tym zakresie ono i jego członkowie mogli co najwyżej lobbować na rzecz rozbudowy powierzchni. Jeśli chodzi natomiast o wzbogacenie zasobu, działania mogły skutkować konkretnymi rezultatami. Zanim więc przedstawię dalsze losy inicjatywy i realizacji zasadniczego celu powołania Towarzystwa, spójrzmy na ówczesną sytuację Biblioteki w zakresie gromadzenia.

Nie trzeba zapewne szczegółowo przypominać, że księgozbiór Biblioteki Uniwersyteckiej tworzony od 1919 roku opierał się na zasobie dawnej Kaiser-Wilhelm-Bibliothek, co stawiało przed jej kierownictwem dwa główne zadania: polonizacji zbiorów i dostosowywania ich do potrzeb tworzonego i stale w tych latach rozwijanego uniwersytetu. Ówczesne sprawozdania pozwalają zarówno wyrobić sobie pogląd na finansowe możliwości Biblioteki dotyczące realizacji tych zadań, jak i wskazać ilościowe efekty rozbudowy księgozbioru dzięki zakupom oraz z wykorzystaniem innych źródeł gromadzenia. Dużą część środków, co pokazuje tabela 1, przeznaczano na zakupy materiałów bibliotecznych, ale i tak ich poziom nie pozwalał na zaspokajanie wszystkich potrzeb. W sprawozdaniu za lata 1927-1937 Vrtel-Wierczyński szacował, że w początkowym okresie na każde 500 złożonych dezyderatów można było zrealizować ok. 300. Poprawa w tym zakresie nastąpiła dopiero w końcowych latach ${ }^{13}$.

Wiadomo, że najważniejsze dla prowadzenia ustalonej, logicznej, długoplanowej polityki gromadzenia zasobów jest posiadanie względnie stałych funduszy przeznaczonych na ten cel. Analiza danych wskazuje niezbicie, że ówczesna dyrekcja Biblioteki borykała się z dużymi problemami w tym zakresie. $Z$ jednej strony była to malejąca, a w końcu zlikwidowana dotacja zwyczajna zmuszająca do intensyfikacji pozyskiwania

11 Archiwum BU, Komisja Biblioteczna od 7.12.1919 do 25.06.1931, sygn. 20, k. 94.

${ }^{12}$ Kronika Uniwersytetu Poznańskiego za rok szkolny 1928/29 za rektoratu prof. dr. Edwarda Lubicz-Niezabitowskiego, Poznań 1930, s. 21.

13 Sprawozdanie Dyrekcji Biblioteki Uniwersyteckiej w Poznaniu za rok akademicki 1936/37 (od 1 września 1936 do 31 sierpnia 1937) oraz Ogólny Pogląd na działalność Biblioteki Uniwersyteckiej w Poznaniu w latach 1927-1937, Poznań 1937, rkps BU 104887 IV, s. 97-98. 
Tabela 1. Środki przeznaczane na materiały biblioteczne w latach 1928-1938

\begin{tabular}{|c|c|c|c|c|c|}
\hline $\begin{array}{c}\text { Rok } \\
\text { akademicki }\end{array}$ & $\begin{array}{c}\text { Dotacja } \\
\text { zwyczajna }\end{array}$ & $\begin{array}{c}\text { Inne } \\
\text { dochody } \\
\text { łącznie }\end{array}$ & $\begin{array}{c}\text { Łącznie suma } \\
\text { dochodów }\end{array}$ & $\begin{array}{c}\text { Kupno } \\
\text { książek } \\
\text { i czasopism }\end{array}$ & $\begin{array}{c}\text { Środki } \\
\text { na nabytki } \\
(\%)\end{array}$ \\
\hline $1928 / 29$ & 32853,85 & 63653,48 & 96507,33 & 52934,55 & 54,85 \\
\hline $1929 / 30$ & 38146,15 & 84481,48 & 122627,63 & 67843,28 & 55,32 \\
\hline $1930 / 31$ & 11930,63 & 54224,72 & 66155,35 & 37050,66 & 56,00 \\
\hline $1931 / 32$ & 9597,84 & 56512,63 & 66110,47 & 35698,49 & 53,99 \\
\hline $1932 / 33$ & 26407,00 & 85912,99 & 112319,99 & 51093,89 & 45,48 \\
\hline $1933 / 34$ & - & 92367,96 & 92367,96 & 37017,18 & 40,07 \\
\hline $1934 / 35$ & - & 90602,24 & 90602,24 & 31568,57 & 34,84 \\
\hline $1935 / 36$ & - & 97173,67 & 97173,67 & 35438,46 & 36,47 \\
\hline $1936 / 37$ & - & 92793,73 & 92793,73 & 33666,40 & 36,28 \\
\hline $1937 / 38$ & - & 90261,98 & 90261,98 & 30370,14 & 33,64 \\
\hline
\end{tabular}

Źródło: opracowanie własne na podstawie sprawozdań rocznych Biblioteki Uniwersyteckiej.

innych dochodów rekompensujących niedobory, z drugiej - wynikające z powyższego duże w stosunkach rocznych zmiany wysokości budżetu. Spadek funduszy nie stanowił okoliczności sprzyjającej rozwojowi Biblioteki, co dyrektor podkreślał w krótkim sprawozdaniu umieszczonym w kronice za rok 1931/32. Pisząc o licznych darach i dziękując za wyrażaną nimi „pocieszającą życzliwość powszechną”, zauważał, że stan budżetu nasuwa smutne refleksje, pozwalające jednoznacznie stwierdzić, że kryzys gospodarczy odbił się na budżecie Biblioteki fatalnie ${ }^{14}$. W pierwszych czterech latach udawało się przeznaczać na gromadzenie ok. 55\% posiadanych środków. Ten wskaźnik jednak ze względu na ograniczenia zmalał poważnie w latach akademickich 1932/33 i 1933/1934, a spadł drastycznie w kolejnych - do poziomu 33-36\%. Tym samym w końcowych latach wydawano na ten cel do 40 , a nawet $50 \%$ pieniędzy mniej niż w początkowych. Moim celem nie jest analiza, na co przeznaczano środki używane dotychczas na gromadzenie, przedstawię zatem tylko, jak wyglądała struktura nabytków.

Widać wyraźnie, że bardzo ważnym, systematycznie wzbogacającym zasoby źródłem nabytków były obowiązkowe egzemplarze biblioteczne dające w tych latach łącznie blisko 39\% wpływów (tab. 2). Zapewniały one jednoegzemplarzowy wpływ bieżącej produkcji wydawniczej, dzięki czemu posiadane środki finansowe można było przeznaczać na

${ }^{14}$ Kronika Uniwersytetu Poznańskiego za rok szkolny 1931/32 za rektoratu prof. dr. Jana Sajdaka, Poznań 1933, s. 172. 
Tabela 2. Źródła nabytków bibliotecznych w latach 1928-1938

\begin{tabular}{|c|r|r|r|r|r|}
\hline $\begin{array}{c}\text { Rok } \\
\text { akademicki }\end{array}$ & Kupno & Wymiana & $\begin{array}{c}\text { Egzemplarz } \\
\text { obowiązko- } \\
\text { wy }\end{array}$ & Dary & Razem \\
\hline $1928 / 29$ & 1323 & - & 6300 & 1752 & 9375 \\
\hline $1929 / 30$ & 914 & 332 & 6527 & 2845 & 10618 \\
\hline $1930 / 31$ & 877 & 541 & 6071 & 3272 & 10761 \\
\hline $1931 / 32$ & 330 & 771 & 5448 & 3440 & 9989 \\
\hline $1932 / 33$ & 558 & 639 & 5340 & 11080 & 17617 \\
\hline $1933 / 34$ & 1324 & 983 & 5425 & 8021 & 15753 \\
\hline $1934 / 35$ & 943 & 1134 & 5914 & 11641 & 19632 \\
\hline $1935 / 36$ & 1227 & 2188 & 7999 & 5509 & 16923 \\
\hline $1936 / 37$ & 1145 & 2242 & 6457 & 21663 & 31507 \\
\hline $1937 / 38$ & 934 & 3533 & 5873 & 5700 & 16040 \\
\hline Łącznie & 9575 & 12363 & 61354 & 74923 & 158215 \\
\hline
\end{tabular}

Źródło: opracowanie własne na podstawie sprawozdań rocznych.

zakup ewentualnie następnych egzemplarzy, a przede wszystkim książek zagranicznych, oraz na uzupełnianie zbiorów, głównie książkami polskimi wydanymi w poprzednich latach czy nawet wiekach. Wpływ z kupna przekroczył ledwie poziom $6 \%$, co pokazuje, w jak niewielkim jednak stopniu można było na nim opierać realizację wskazanych zadań. Statystyki te uświadamiają także, w jak trudnej sytuacji znajdowała się dyrekcja Biblioteki, i przekonują, że szukanie pomocy zewnętrznej, w tym również powołanie do życia Towarzystwa Przyjaciół Biblioteki było uzasadnione. Pokazuja że próby pozyskiwania darów i tworzenia grup lobbujących były próbami ratowania i polepszania sytuacji $\mathrm{w}$ zakresie budowania zasobu.

Przywoływane uprzednio posiedzenie Komisji Bibliotecznej odbywało się w końcu czerwca 1928 roku, a dalszy oficjalny tok pracy przerwała letnia kanikuła. Jednakże zachowane dokumenty pozwalają stwierdzić, że w tym właśnie czasie Vrtel-Wierczyński prowadził już wstępne rozmowy, a rozpoczął je zapewne od prof. Ludwika Ćwiklińskiego, powszechnie szanowanego doktora honorowego uniwersytetu, zwanego często w korespondencji Panem Ministrem, ze względu na pełnioną w latach 1917-1919 funkcję ministra oświaty w Wiedniu. 31 października skierował do niego pismo, do którego zgodnie z wyrażonym wcześniej życzeniem dołączył - niezachowany niestety $\mathrm{w}$ aktach - spis proponowanych członków założycieli Towarzystwa i projekt odezwy. Kończył list pytaniem o terminy spotkań z wojewoda, starostą krajowym i prezydentem miasta, 
co pokazuje planowany rozmach działań ${ }^{15}$. Kilka dni później - jak przed laty Henryk Likowski - zwrócił się do dyrekcji Biblioteki Jagiellońskiej z prośbą o przekazanie egzemplarza statutu oraz sprawozdania towarzystwa ${ }^{16}$. Na prośbę pozytywnie odpowiedział dyrektor Kuntze, przesyłając 3 grudnia statut wraz z informacja, że odpisów sprawozdań towarzystwo nie posiada ${ }^{17}$. Podobny list musiał być skierowany do Lwowa, bo także 3 grudnia kustosz Zakładu Narodowego im. Ossolińskich przesyłał niezachowany w dokumentacji - Statut Towarzystwa Przyjaciół Ossolineum ${ }^{18}$. Dzień po wysłaniu zapytań do Krakowa i Lwowa Vrtel-Wierczyński przesłał Ćwiklińskiemu do akceptacji tekst zaproszenia i listu wyjaśniającego cele mającego się zawiązać towarzystwa wraz z prośbą o wstępną zgodę na podpisanie odezwy, którą komitet organizacyjny w najbliższym czasie opracuje. Do podpisania odezwy, poza oczywiście Ćwiklińskim i Wierczyńskim, miały zostać zaproszone następujące osoby: wojewoda Adolf hr. Bniński, szambelanowa Paulina Cegielska, mecenas Ludwik Cichowicz, hr. August Cieszkowski, profesorowie: Bronisław Dembiński, Bolesław Erzepki, Tadeusz Grabowski, radca Stefan Kałamajski, ks. prałat Józef Kłos, minister Wanda Korytowska, ks. prof. Stanisław Kozierowski, dr Bolesław Krysiewicz, biskup gnieźnieński Antoni Laubitz, hr. Stanisław Niegolewski, prof. Edward Lubicz-Niezabitowski, hr. Roger Raczyński, hr. Jan Żółtowski z Czacza ${ }^{19}$. W kolejnych dniach Vrtel-Wierczyński skierował do nich stosowne pisma, powiększając grono zaproszonych o prof. Adama Żółtowskiego ${ }^{20}$, później także senatora Bernarda Chrzanowskiego i prof. Jana Rutkowskiego ${ }^{21}$. Odezwę, bez zapraszania do udziału w spotkaniu, wysłał także do prymasa Polski kardynała Augusta Hlonda ${ }^{22}$, który w odpowiedzi życzył Towarzystwu pomyślnego rozwoju i dołączał stosowne błogosławieństwo ${ }^{23}$. Vrtel-Wierczyński prosił wszystkich o podpisanie załączonej odezwy datowanej na grudzień 1928 roku. Dzienna data pod odezwą nie była zapewne najważniejsza, ale ogólny zapis „grudzień 1928” wraz z zachowanymi informacjami

${ }^{15}$ Archiwum BU, Towarzystwo Przyjaciół Biblioteki, sygn. 25, list Stefana Vrtela-Wierczyńskiego do Ludwika Ćwiklińskiego z 31.10.1928, k. 3.

${ }^{16}$ Ibidem, list Stefana Vrtela-Wierczyńskiego z 16.11.1928, k. 4.

${ }^{17}$ Ibidem, list Edwarda Kuntzego z 3.12.1928, k. 26.

${ }^{18}$ Ibidem, list z 3.12.1928, k. 15.

${ }^{19}$ Ibidem, załącznik do listu Stefana Vrtela-Wierczyńskiego z 18.11.1928, k. 7.

${ }^{20}$ Ibidem, wykaz adresatów listów, k. 19.

${ }^{21}$ Ibidem, Projekt zaproszenia z 13.03.1929, k. 32.

${ }^{22}$ Ibidem, projekt tekstu listu wraz z adnotacją „wysł. dn. 26. IV. 29”, k. 63.

${ }^{23}$ Ibidem, odpis listu Augusta kardynała Hlonda z 18.05.1929, k. 65. 
o kilkakrotnym przesuwaniu terminu zwołania zebrania konstytuującego pokazuje trudność w doprecyzowaniu wszelkich szczegółów tego, uważanego za ważne, przedsięwzięcia. Troskę o ich skonkretyzowanie widać też na zachowanych maszynopisach projektu statutu $\mathrm{w}$ postaci nanoszonych nań uwag. Jednocześnie przygotowywano ostateczny tekst odezwy W sprawie potrzeb Biblioteki Uniwersyteckiej w Poznaniu, datowanej na kwiecień roku 1929, będący zmodyfikowaną wersją propozycji z grudnia poprzedniego roku (il. 1 i 2). $W$ niej to podawano ostateczną datę zebrania założycielskiego - 2 maja 1929 roku. Odezwa podpisana została przez większość z osób, do których wystosowano wcześniejsze zaproszenia $^{24}$ oraz dr. Czesława Meissnera. Celem szerokiego rozkolportowania informacji 24 kwietnia Vrtel-Wierczyński wysłał odezwę do pięciu redakcji czasopism („Kuriera Poznańskiego”, „Dziennika Poznańskiego”, "Gazety Zachodniej”, ,Kuriera Nowego" i „Tęczy”) wraz z pismem przewodnim, w którym prosił o jej wydrukowanie w jednym $\mathrm{z}$ najbliższych numerów ${ }^{25}$. W kolejnych dniach została ona wysłana do 13 redakcji pism krakowskich, lwowskich, toruńskich i warszawskich. Redakcja „Kuriera Poznańskiego" - jako jedyna z poznańskich - przedrukowała całą odezwę, poprzedzając ją komentarzem wstępnym, w którym stwierdzano, że oto jest do odnotowania fakt radosny i pełen znaczenia dla kultury narodowej w Poznaniu, bo „[d]zięki zabiegom ludzi dobrej woli i szerokiego horyzontu powstaje u nas Towarzystwo Przyjaciół Biblioteki Uniwersyteckiej" ${ }^{26}$. Można więc założyć, że dzięki tym staraniom idea była promowana i docierała do szerokich kręgów odbiorców.

Odezwa składa się z siedmiu akapitów, z których pierwsze poświęcono podkreśleniu rosnącej roli bibliotek, w tym szczególnie naukowych, przypomnieniu tradycji powstawania księgozbiorów dzięki ofiarności mecenasów oraz podaniu przykładów powołanych już towarzystw jako społecznej odpowiedzi na wezwanie do udzielenia wsparcia bibliotekom polskim. W kolejnym akapicie krótko przypomniano historyczny początek Biblioteki Uniwersyteckiej i wskazano na działania dyrekcji w celu zminimalizowania wszelkich dostrzeganych, zwłaszcza w jej zasobach, niedostatków. Kończono odezwę apelem „do społeczeństwa Wielkopolski zawsze tak chętnie składającego ofiary na cele publiczne [...], by z okazji jubileuszowego obchodu 10-lecia Uniwersytetu Poznańskiego zechciało ponownie dać wyraz Swej dlań życzliwości i nietylko udzieliło

${ }^{24}$ Nie znajdujemy wśród sygnatariuszy Pauliny Cegielskiej, Stefana Kałamajskiego, Bernarda Chrzanowskiego i Jana Rutkowskiego.

${ }^{25}$ Ibidem, list Stefana Vrtela-Wierczyńskiego z 24.04.1929, k. 61.

${ }^{26}$ Por. przypis 2. 


\section{W sprawie potrzeb \\ Bibljoteki Uniwersyteckiej w Poznaniu.}

$\mathrm{Z}$ niezrównanym wzrostem różnych gałęzi nauki i pogłębieniem ich metod w ostatnich lat dziesiątkach, pomnożyły się zarazem zadania i potrzeby zakładów naukowych, osobliwie tych, które stanowią najogólniejsze i najważniejsze warsztaty pracy - publicznych bibljotek naukowych. Związane przeważnie $\mathrm{z}$ akademickiemi uczelniami, służą one nietylko badaniom uczonych, lecz także przysposobieniu przyszłych pracowników naukowych i tych, którzy wyniki badań mają uprzystępniać i rozpowszechniać. Im przeto większy i zasobniejszy jest księgozbiór, tem rozleglejszy jest zakres jego wplywów, tem obfitsze plyna zen korzyści. Utrzymywanie i zaopaîrywanie bibliotek w nowe zabytki wymaga jednak tak dużych nakładów, że nie może dokonywać się wyłącznem staraniem skarbu publicznego: wszędzie też współdziałaja społeczeństwa.

U nas w Polsce oddawna powstawały księgozbiory ofiarnością wielkodusznych mecenasów; - jaśnieją nazwiska Załuskich, Ossolińskich, Działyńskich, Raczyńskich, oraz tych dobrodziejów, którzy hojnemi darami przykładali się do wzbogacenia Bibljotek: Jagiellońskiej $\mathrm{i}$ uniwersyteckich w Warszawie i Lwowie. W obecnej chwili wskutek wymagań zwiększonych bibljoteki nasze w szczególnej mierze potrzebują poparcia ze strony Spoleczeństwa.

W uznaniu tej potrzeby powstało w Krakowie Towarzystwo Przyjaciół Bibljoteki Jagiellońskiej, we Lwowie Towarzystwo Przyjaciół Ossolineum, w Wilnie Towarzystwo Przyjaciół Bibljoteki Uniwersyteckiej, a w ostatnim czasie wyłoniła się myśl powołania do życia Towarzystwa Przyjaciól Bibljoteki-Uniwersyteckiej w Poznaniu.

Założony pod nazwą Bibljoteki cesarza Wilhelma $\mathrm{w}$ celach nie tyle naukowych, ile oświatowych i germanizacyjnych, po części $\mathrm{z}$ darów bibljotek $\mathrm{i}$ nakładców niemieckich, Zakład ten nie stanowił całości jednolitej, lecz miał raczej cechę zbioru przypadkowego, a posiadal w różnych dziedzinach, zwłaszcza w dziale piśmiennictwa polskiego i slawistyki luki i braki bardzo duże.

Te niedostatki do dnia dzisiejszego, mimo zabiegów Zarządu, zaledwie w części usunąć zdołano, skromne bowiem fundusze, jakiemi Bibljoteka rozporządza, nie wystarczają nawet na zaspokojenie potrzeb bieżących, jak abonament czasopism, zakup dzieł najniezbędniejszych, oprawa książek, nie można zaś było nawet pomyśleć o nabywaniu rękopisów $\mathrm{i}$ archiwaljów albo kosztownych wydawnictw $\mathrm{z}$ zakresu nauk przyrodniczych, historji sztuki $\mathrm{i}$ archeologii.

\section{Il. 1. Tekst odezwy W sprawie potrzeb Bibljoteki Uniwersyteckiej w Poznaniu (s. 1)} Źródło: zbiory Archiwum BU w Poznaniu. 
Zachodzi więc konieczna potrzeba uzupełnienia naszej Bibljoteki Uniwersyteckiej i zasilenia jej przedewszystkiem w tych działach, w których luki są największe, a niemniej potrzebne jest zabezpieczenie jej dalszego pomyślnego rozwoju.

Grono osób, podpisanych pod niniejszą odezwą, zwraca się do Spoleczeństwa Wielkopolskiego, zawsze tak chętnie składającego ofiary na cele publiczne, z gorąca prośba, by z okazii jubileuszowego obchodu 10-lecia Uniwersytetu Poznańskiego zechciało ponownie dać wyraz Swej dlań życzliwości i nietylko udzieliło Bibliotece Uniwersyteckiej jednorazowej pomocy, lecz zapewniło jej stałą troskliwą opiekę, przystępując licznie do Towarzystwa Przyjaciół tejże Bibljoteki.

Posiedzenie, na którem Towarzystwo ma się ukonstytuować, odbedzie się w. czwartek, dnia 2 maja 1929 r. o godz. 6-tej w parterowej sali Bibljoteki Uniwersyteckiej.

W Poznani u, w kwietniu 1929 r.

Adolf $h r$. Bninski, Gułtowy Ludwik Cichowicz, Poznań August hr. Cieszkowski, Wierzenica Dr. Ludwik Ćwikliński, Poznań Dr. Bronisław Dembiniski, Poznań Dr. Bolesíaw Erzepki, Poznań Dr. Tadeusz Grabowski, Poznań X. Pralat Józef Klos, Poznań Wanda Korytowska, Poznań X. Dr. Stanisłáw Kozierowski, Skórzewo
Dr. Boleslaw Krysiewicz, Poznań X. Biskup Laubitz, Gniezno

Dr. Czeslaw Meissner, Poznań Stanislaw Niegolewski, Niegolewo

Dr. Edward Lubicz-Niezabitowski Poznań

Roger hr. Raczyriski, Rogalin Dr. Stefan Wierczyński, Poznań Dr. Adam Żóltowski, Poznań Jan hr. Żoltowski, Czacz.

Il. 2. Tekst odezwy W sprawie potrzeb Bibljoteki Uniwersyteckiej w Poznaniu (s. 2) Źródło: zbiory Archiwum BU w Poznaniu. 
Bibljotece Uniwersyteckiej jednorazowej pomocy, lecz zapewniło jej stałą troskliwą opiekę, przystępując licznie do Towarzystwa Przyjaciół tejże Biblioteki"27. Zwraca uwagę powiązanie założenia Towarzystwa z faktem 10-lecia powołania uczelni.

Zebranie konstytuujące Towarzystwo, któremu przewodniczył prof. Ludwik Ćwikliński, odbyło się 2 maja 1929 roku, a jego przebieg dokładnie przedstawiono w „Kurierze Poznańskim” ${ }^{28}$. Relację zatytułowaną Przyjaciele Bibljoteki Uniwersyteckiej zaczelli prace poprzedzały dwa akapity wstępne, w których wskazywano na duży zakres prac wykonanych przez 10 lat od momentu powołania Biblioteki w celu dostosowania jej do zadań uniwersytetu, z równoczesnym podkreśleniem faktu, że nie wszystkie potrzeby zostały zaspokojone i należy zrealizować jeszcze wiele działań. Skupiano się głównie na budowie zasobu: „idzie o rzecz nie małą: o to, by książka polska, a z nią kultura polska przeniknęła księgozbiór do głębi, by braki w dziedzinie rzeczy polskich i słowiańskich wogóle w jak najkrótszym czasie zostały zapełnione. Słowem, by księgozbiór był polski nie tylko z nazwy, ale i z treści swej i z ducha". Wskazywano dalej, że poza polonistyką i slawistyką czekają na uzupełnienie takie działy jak: przyroda, medycyna, geografia, matematyka, romanistyka i inne. Podsumowywano tę część stwierdzeniem, że potrzebami Biblioteki powinno zainteresować się społeczeństwo w imię dobra kultury i nauki polskiej. Po tym wstępie pokazującym, jak poważnie traktowano nie tylko samą ideę powołania towarzystwa, ale też konieczność wsparcia książnicy, aby mogła właściwie wspomagać realizację celów stawianych przed nauką polska, poinformowano, że wzorem Krakowa, Lwowa i Wilna również w Poznaniu powstało stosowne towarzystwo. W zebraniu założycielskim, poza wcześniej wymienionymi sygnatariuszami odezwy, udział wzięli: senator Bernard Chrzanowski, księżna Zdzisławowa Czartoryska, Stefan Demby - naczelnik Wydziału Bibliotek Państwowych w Ministerstwie Wyznań Religijnych i Oświecenia Publicznego, prof. Jan Grochmalicki, dr Zofia Kawecka, wiceprezydent Mikołaj Kiedacz, dr Nikodem Pajzderski, Antonina Spychalska, wicekurator Ignacy Stein, dr Bożena Szulc-Golska, prof. Henryk Ułaszyn, Stanisław Wacławik, dyrektor Józef Winiewicz, dr Kazimierz Wize. Następnie zrelacjonowano przemówienie przewodniczącego zebrania - prof. Ćwiklińskiego, który, wskazując na wzrastającą wagę bibliotek w budowaniu warsztatu dla prowadzenia i następnie upowszechniania wyników badań naukowych na całym świecie, ich wszechstronny rozwój, wyraził życzenia, aby i nauka polska

\footnotetext{
27 Odezwa W sprawie potrzeb Bibljoteki Uniwersyteckiej w Poznaniu, s. 2.

28 „Kurier Poznański”, nr 215 z 10.05.1929, s. 8.
} 
mocno zaznaczyła swój udział w nauce światowej i by książnice polskie, w tym i uniwersytecka w Poznaniu mogły się do tego przyczyniać. Wystąpienie kończył apelem o udzielenie jej pomocy, aby te marzenia stały się rzeczywistością. W kolejnym etapie zebrania przedyskutowano i uchwalono projekt statutu oraz wybrano wydział Towarzystwa. Przewodniczącym został prof. Ludwik Ćwikliński, zastępcami prof. Tadeusz Grabowski i hr. Roger Raczyński, członkami: starosta krajowy Ludwik Begale, hr. Adolf Bniński, senator Bernard Chrzanowski, prof. Bolesław Erzepki, prof. Antoni Władysław Jakubski, redaktor Witold Noskowski, hr. Stanisław Żółtowski z Wargowa, delegat Senatu Akademickiego ${ }^{29}$ oraz dyrektor Biblioteki Uniwersyteckiej doc. dr Stefan Vrtel-Wierczyński. Do komisji rewizyjnej wybrano prof. Zygmunta Lisowskiego, prof. Adama Wrzoska i wicekuratora Ignacego Steina. W zakończeniu relacji podkreślono jako ważny głos naczelnika Stefana Dembego, który, wyrażając radość z powodu powołania Towarzystwa, przyrzekł w imieniu czynników rządowych poparcie jego działalności. Członkiem wydziału została wybrana także dr Maria Wojciechowska, której nazwisko w relacji prasowej pominięto, o czego uzupełnienie prosił Vrtel-Wierczyński redakcję już $\mathrm{w}$ dniu publikacji ${ }^{30}$. Dość szybko, bo na posiedzeniu wydziału 16 grudnia 1929 roku przewodniczący poinformował, że hr. Raczyński i hr. Żółtowski zrzekli się mandatu członka wydziału. Na tym samym posiedzeniu do pełnienia funkcji sekretarza powołano dr Wojciechowska, zastępcy sekretarza - dr. Noskowskiego, a skarbnika - Vrtela-Wierczyńskiego, którego zastępcę postanowiono wybrać w późniejszym terminie ${ }^{31}$.

Uchwalony w czasie posiedzenia statut jest stosunkowo obszernym dokumentem, opartym mocno na akcie otrzymanym z Krakowa. Składa się z 10 rozdziałów i 22 rozbudowanych paragrafów. Nie ma potrzeby przytaczać wszystkich zapisów, bo jak każdy tego typu dokument zawierał wiele stałych punktów dotyczących: nazwy i siedziby; wskazania celu, który określano krótko jako „popieranie interesów i rozwój Biblioteki Uniwersyteckiej w Poznaniu"; środków służących jego realizacji, które właściwie powtórzyły przytoczony już wcześniej zapis proponowany przez Grycza. W rozdziale IV poświęconym członkom ustanawiano trzy ich grupy: członka zwyczajnego, którym mogła być osoba fizyczna lub

${ }^{29}$ Należałoby stwierdzić, że dla delegata Senatu właściwie rezerwowano w tym momencie miejsce, bo o jego wskazanie proszono Senat dopiero pismem z 29.10.1929, k. 78. Delegatem został na posiedzeniu Senatu UP 8 listopada prof. Edward Lubicz-Niezabitowski. Ibidem, list Rektora UP z 14.11.1929, k. 82.

${ }^{30}$ Archiwum BU, Towarzystwo Przyjaciół Biblioteki, sygn. 25, list Stefana Vrtela-Wierczyńskiego do Redaktora Latoszewskiego z 10.05.1929, k. 64.

${ }^{31}$ Ibidem, protokół posiedzenia z 16 grudnia 1929, k. 86. 


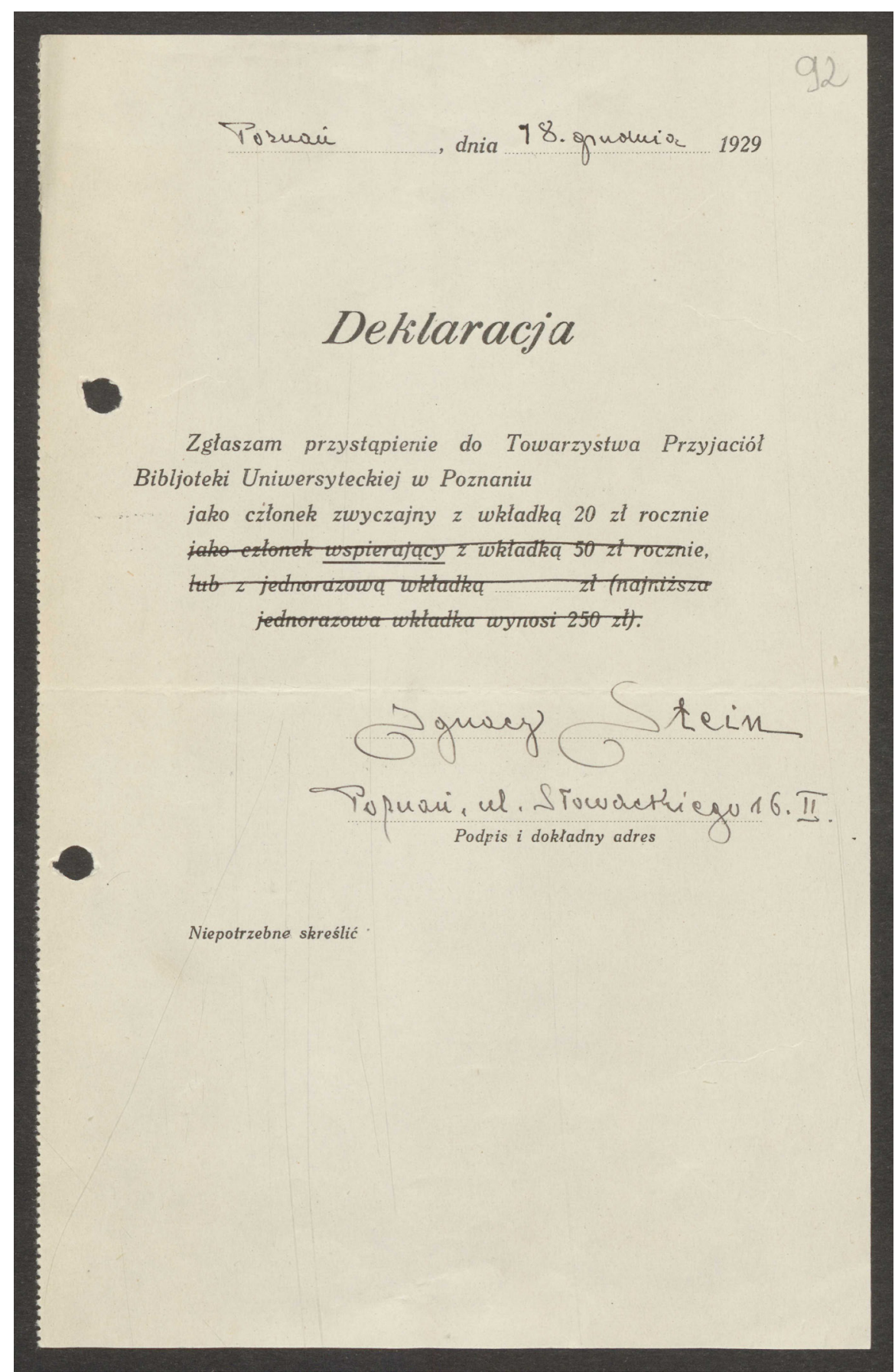

Il. 3. Deklaracja członkowska Ignacego Steina Źródło: zbiory Archiwum BU w Poznaniu. 
prawna opłacająca składkę roczną w wysokości 6 zł; członka wspierającego płacącego składkę roczną w wysokości 50 zł lub wpłacającego jednorazowo 250 zł; członka honorowego, którym mogła zostać osoba fizyczna lub prawna, kładąca szczególne zasługi dla Towarzystwa lub Biblioteki Uniwersyteckiej - godność tę mogło nadawać walne zgromadzenie na wniosek wydziału. Dalej precyzowano zasady przyjmowania w poczet członków zwyczajnych i wspierających; zasady rezygnacji czy wykreślenia z listy; prawa i obowiązki członków. Rozdział VII określał, że dochodami są składki, odsetki od funduszów, darowizny we wszelkiej formie oraz dochody z publikacji, odczytów itp. Służyć one miały pokrywaniu kosztów administracji, publikacji oraz zakupu druków i rękopisów. Zaznaczano również, że wszelkie dary „w postaci przedmiotów bibliotecznych przechodzą automatycznie na własność Biblioteki Uniwersyteckiej". Kolejne rozbudowane rozdziały stanowiły o władzach Towarzystwa, w tym zadaniach walnego zgromadzenia, wydziału i zarządu oraz komisji rewizyjnej, rozsądzaniu sporów oraz trybie i warunkach rozwiązania Towarzystwa ${ }^{32}$.

Statut został skierowany do Sądu Grodzkiego 23 grudnia 1929 roku w celu rejestracji Towarzystwa, co zostało zrealizowane po wpłaceniu wskazanej przez sąd ustawowej opłaty na pokrycie kosztów wpisu i ogłoszenia w wysokości $35 \mathrm{z}^{33}$.

Dalsze losy Towarzystwa można śledzić na podstawie informacji umieszczanych na łamach corocznych sprawozdań Biblioteki, a także Kroniki Uniwersytetu. W sprawozdaniu z roku akademickiego 1929/30 ${ }^{34}$ informowano, że Towarzystwo poddano reorganizacji, polegającej na drobnych korektach w statucie, koniecznych dla zarejestrowania go jako osoby prawnej. Działalność Towarzystwa skoncentrowana była na działaniach propagandowych, co skutkowało przekazywaniem darów. Jako najważniejszy wśród nich wymieniano liczący 145 tomów cennych czasopism dar hr. Leona Żółtowskiego z Niechanowa, choć wśród najhojniejszych darczyńców znajdujemy także przewodniczącego Towarzystwa, prof. Ćwiklińskiego, który przekazał 256 tomów z zakresu filologii klasycznej, dając tym samym przykład nie tylko członkom Towarzystwa. Zmienił się też zarząd Towarzystwa, bo choć nadal przewodniczącym

32 Ibidem, statut Towarzystwa Przyjaciół Bibljoteki Uniwersyteckiej w Poznaniu, k. 97-102.

33 Ibidem, odpis pisma Sądu Grodzkiego z 27.12.1929, k. 96.

${ }^{34}$ Sprawozdanie Dyrekcji Biblioteki Uniwersyteckiej w Poznaniu za rok akademicki 1929/30 (od 1 września 1929 do 31 sierpnia 1930), Poznań 1930, rkps BU 104887 IV, s. 8-9. 
pozostawał prof. Ludwik Ćwikliński, to jako pierwszego zastępcę wskazywano Adolfa hr. Bnińskiego, jako drugiego - prof. dr. Tadeusza Grabowskiego. Funkcję sekretarza powierzono dr Zofii Kaweckiej, której zastępcą był red. Witold Noskowski, skarbnikiem dr Stanisław Bąkowski, a jego zastępcą Franciszek Zygarłowski. Ponadto skład zarządu uzupełniali: prof. dr Edward Lubicz-Niezabitowski jako przedstawiciel senatu akademickiego oraz dyrektor Biblioteki prof. Vrtel-Wierczyński. W tym składzie - co potwierdzają kolejne sprawozdania roczne - zarząd pracował już do wybuchu wojny. Skład zarządu był sprawą niezwykle ważna, gdyż stanowiące go osoby miały swą powagą wpływać na innych i skłaniać ich do wspierania Biblioteki bezpośrednimi darami lub Towarzystwa np. finansami, które przeznaczane byłyby na potrzeby książnicy.

W tym właśnie duchu kolejne sprawozdanie ${ }^{35}$ przynosi informacje, że zarząd Towarzystwa przyczynił się swymi działaniami do pozyskania wielu darów i zakupu potrzebnych dzieł naukowych. Dzięki pośrednictwu przewodniczącego pozyskano od Zarządu Akademii Wiedeńskiej 77 tomów sprawozdań naukowych „Sitzungsberichte der Kaiserlichen Akademie der Wissenschaften" komisji filozoficzno-historycznej oraz matematyki i nauk przyrodniczych, a także stały 50-procentowy rabat na zakup dalszych tomów tegoż wydawnictwa. Wskazano też trzy tytuły (w siedmiu tomach) zakupionych książek, poinformowano, że zarząd Towarzystwa stara się uwzględnić najpilniejsze dezyderaty, bo z braku środków nie może niestety zaspokoić wszystkich potrzeb. Ta pomoc była w tym czasie niezwykle potrzebna, bo - jak zaznaczano - sytuacja finansowa Biblioteki w roku sprawozdawczym 1930/31 znacznie się pogorszyła, gdyż otrzymano jedynie 11 930,63 zł dotacji zwyczajnej, podczas gdy rok wcześniej wyniosła ona 38 143,15 zł.

W kolejnym roku zakupiono 13 dzieł zagranicznych w 17 tomach oraz 16 dzieł polskich z księgozbioru śp. dr. Teodora Tyca. Wśród nich dominowały książki nowe, pochodzące z lat 1931-1932. Stanowiły one zatem element bieżącego gromadzenia, gdyż tylko trzy tomy można uznać za uzupełnianie zasobów (Heinricha Günthera Buddha in der abendländischen Legende? z 1922; Die Kindheit Jesu, zwei apokryphe Evangelien z 1924 oraz Ludwiga Pfandla Spanische Nationalliteratur z 1919 roku). Wszystkie zakupione książki, poza dwiema francuskojęzycznymi, opublikowane były w języku niemieckim. Ich tematyka była różna - dotyczyły teologii,

35 Sprawozdanie Dyrekcji Biblioteki Uniwersyteckiej w Poznaniu za rok akademicki 1930/31 (od 1 września 1930 do 31 sierpnia 1931), Poznań 1931, rkps BU 104887 IV, s. 8-9. 
literatury, historii, chemii. Wśród ważnych dzieł można wskazać jedno na temat historii regionalnej Alfreda Grotte (Bürgerhaus in der Posener Landen, Wrocław, 1932) i kolejny tom znanego opracowania Johana Huizingi (Herbst des Mittelälters, 1931) $^{36}$. Podsumowując rok akademicki 1931/32 w czasie uroczystej inauguracji kolejnego roku, rektor prof. dr Jan Sajdak dziękował za pomoc w rozwoju zasobów Biblioteki. Po raz pierwszy od chwili powołania $\mathrm{w}$ tak ważnym momencie roku akademickiego podkreślił, że Towarzystwo „dużo zdziałało w tym kierunku” ${ }^{37}$, co należy

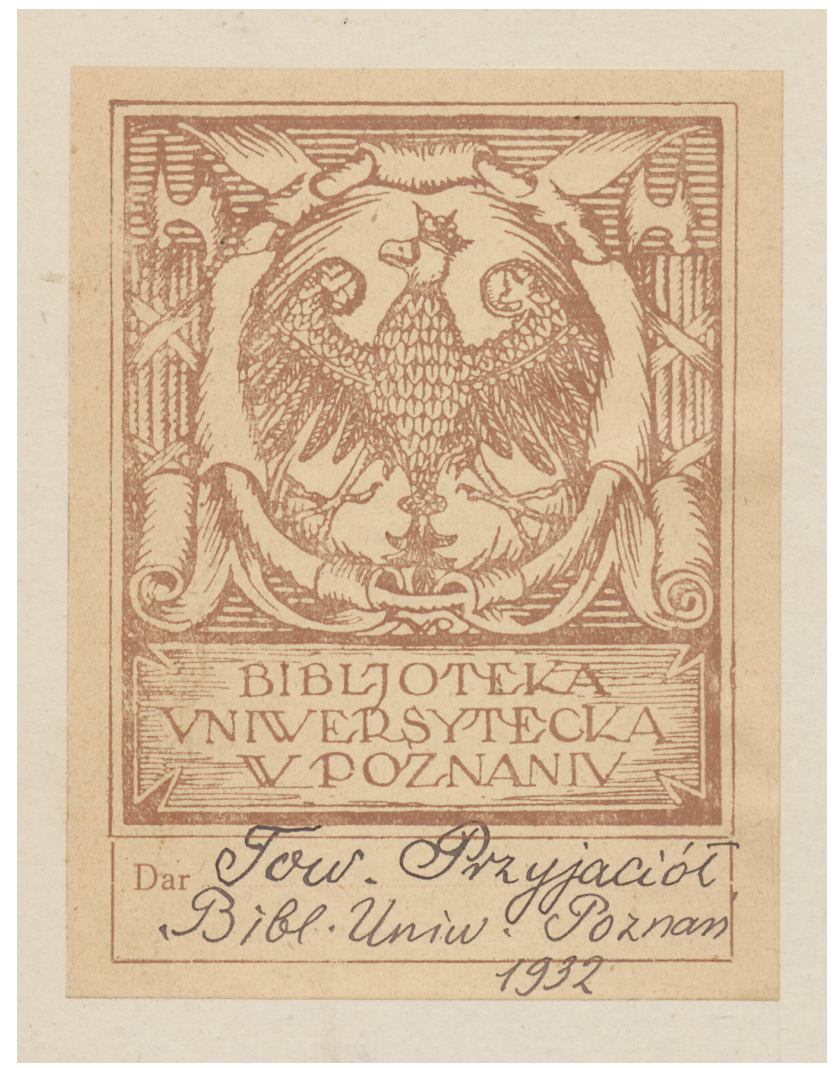

Il 4. Ekslibris Biblioteki Uniwersyteckiej informujący, iż oznaczona nim książka jest darem TPBU Źródło: zbiory Archiwum BU w Poznaniu.

${ }^{36}$ Sprawozdanie Dyrekcji Biblioteki Uniwersyteckiej w Poznaniu za rok akademicki 1931/32 (od 1 września 1931 do 31 sierpnia 1932), Poznań 1932, rkps BU 104887 IV, s. 8-9.

${ }^{37}$ Kronika Uniwersytetu Poznańskiego za rok szkolny 1931/32 za rektoratu prof. dr. Jana Sajdaka, Poznań 1933, s. 17. 
odebrać jako duże słowa uznania. W kolejnych sprawozdaniach powtarzały się podobne określenia kierowane pod adresem Towarzystwa.

Rok akademicki 1932/33 nazwano rokiem „wydatnej pomocy”38, gdyż Towarzystwo zakupiło z własnych funduszy aż 128 dzieł w 129 tomach, w tym komplet (121 tomów) serii I Biblioteki Narodowej. Nabyto ją na wyraźną prośbę dyrektora Vrtela-Wierczyńskiego, który uzyskał u wydawcy 40-procentowy rabat, w związku z czym całość kosztowała $202 \mathrm{zł}^{39}$. Na pozostałych osiem tomów złożyło się siedem niemieckojęzycznych dzieł z bieżącej produkcji wydawniczej. Jako ważne podkreślono również to, że Towarzystwo w połowie sfinansowało zakup kopii obrazu Jana Matejki Założenie Akademii Lubrańskiego, wykonanej przez artystę Stefana Bukowskiego.

Kolejny rok działalności Towarzystwa zaowocował zakupieniem łącznie 29 dzieł w 38 tomach, głównie niemieckojęzycznych, wydanych w ostatnich latach w Gdańsku i Królewcu, co nazywano wzbogaceniem księgozbioru o cenne dzieła z zakresu literatury pomorzoznawczej. Zwrócono też uwagę na zakup 10 publikacji w 18 tomach wydanych staraniem Jana K. Żupańskiego, stanowiących uzupełnienie wcześniejszych edycji tej oficyny wydawniczej znajdujących się już w księgozbiorze ${ }^{40}$. W ostatnim akapicie zaznaczono, że rok ten obfitował pokaźnymi darami indywidualnymi złożonymi przez członków Towarzystwa ${ }^{41}$.

W sprawozdaniu za rok akademicki 1934/35 odnajdujemy tylko skrótową informację, że na książki dla Biblioteki Towarzystwo wydało 623 zł - zakupiono cenne z punktu widzenia repolonizacji zbiorów czterotomowe warszawskie wydanie z 1806 roku Maurycego A. Beniowskiego Historii podróży y osobliwszych zdarzeń sławnego..., dalej 20 tomów ze znacznie szerszej lipskiej edycji Analecta Hymnica oraz sztych Pierwsze posiedzenie

${ }^{38}$ Sprawozdanie Dyrekcji Biblioteki Uniwersyteckiej w Poznaniu za rok akademicki 1932/33 (od 1 września 1932 do 31 sierpnia 1933), Poznań 1933, rkps BU 104887 IV, s. 7. W sprawozdaniu umieszczonym na łamach Kroniki Uniwersytetu Poznańskiego za rok szkolny 1932/33 za rektoratu prof. dr. Stanisława Pawłowskiego (Poznań 1934, s. 161) stwierdzono, że Towarzystwo zakupiło 166 woluminów cennych dzieł naukowych.

${ }^{39}$ Archiwum BU, Towarzystwo Przyjaciół Biblioteki, sygn. 25, list Stefana Vrtela-Wierczyńskiego z 24.11.1932, k. 113.

${ }^{40}$ Były to m.in. edycje prac Joachima Lelewela i kilkanaście tomów serii „Pamiętników z ósmnastego wieku". Zob. Archiwum BU, Towarzystwo Przyjaciół Biblioteki, sygn. 25, wykaz z 25.11.1934, k. 122.

${ }^{41}$ Sprawozdanie Dyrekcji Biblioteki Uniwersyteckiej w Poznaniu za rok akademicki 1933/34 (od 1 września 1933 do 31 sierpnia 1934), Poznań 1934, rkps BU 104887 IV, s. 9 oraz Kronika Uniwersytetu Poznańskiego za rok szkolny 1933/34 za rektoratu prof. dr. Stanisława Rungego, Poznań 1935, s. 226. 
Ligi Polskiej w Kórniku². Kolejny rok okazał się chudy, gdyż według sprawozdania Towarzystwo zakupiło jedynie dwa dzieła w trzech tomach ${ }^{43}$. Jeszcze skromniejsze są zapisy dotyczące następnego roku - ograniczono się do ogólnego stwierdzenia, że działalność Towarzystwa „idzie w dalszym ciągu po linii wytyczonej, tj. rozwija się w kierunku przysparzania księgozbiorowi potrzebnych dzieł naukowych drogą kupna lub daru"44. Podobnie w ostatnim już sprawozdaniu odnotowano zakup czterech książek z produkcji bieżącej, przy czym - co warto podkreślić - były to wyłącznie książki polskie wydane w Krakowie i Warszawie. Zakup uzupełniły nieokreślone dary pochodzące od członków Towarzystwa lub jak zapisano - uzyskane dzięki ich staraniom ${ }^{45}$.

Interesujące jest pytanie o to, kto jeszcze poza wyżej wskazanymi należał do Towarzystwa i ilu liczyło ono członków. Niestety w dokumentacji brak listy członków Towarzystwa, ewentualnych protokołów z posiedzeń pozwalających określić częstotliwość i systematyczność spotkań, jak też informacji o składkach czy donacjach, a tym samym o podstawowym źródle jego dochodów. Na jednej z ręcznie sporządzonych list pojawiają się, poza już znanymi, nazwiska Mieczysława Chłapowskiego z Kopaszewa, profesorów Alfreda Denizota i Henryka Ułaszyna ${ }^{46}$ oraz na zaproszeniu wystosowanym 11 października 1933 roku przez dyrektora Vrtela-Wierczyńskiego na uroczystość otwarcia nowej Czytelni Czasopism do wspominanego już wicekuratora Steina oraz niezidentyfikowanego por. J. Jankowskiego ${ }^{47}$.

Brak $\mathrm{w}$ dokumentacji materiałów księgowych pozwalających określić wysokość i systematyczność wpływów. Chyba nie były zbyt liczne

42 Sprawozdanie Dyrekcji Biblioteki Uniwersyteckiej w Poznaniu za rok akademicki 1934/35 (od 1 września 1934 do 31 sierpnia 1935), Poznań 1935, rkps BU 104887 IV, s. 9.

${ }^{43}$ Sprawozdanie Dyrekcji Biblioteki Uniwersyteckiej w Poznaniu za rok akademicki 1935/36 (od 1 września 1935 do 31 sierpnia 1936), Poznań 1936, rkps BU 104887 IV, s. 19-20.

${ }^{44}$ Sprawozdanie Dyrekcji Biblioteki Uniwersyteckiej w Poznaniu za rok akademicki 1936/37 (od 1 września 1936 do 31 sierpnia 1937) oraz Ogólny Pogląd na działalność Biblioteki Uniwersyteckiej w Poznaniu w latach 1927-1937, Poznań 1937, rkps BU 104887 IV, s. 19.

${ }^{45}$ Sprawozdanie Dyrekcji Biblioteki Uniwersyteckiej w Poznaniu za rok akademicki 1937/38 (od 1 września 1937 do 31 sierpnia 1938), Poznań 1938, rkps BU 104887 IV, s. 16.

${ }^{46}$ Archiwum BU, Towarzystwo Przyjaciół Biblioteki, sygn. 25, odręczna notatka Stefana Vrtela-Wierczyńskiego, b.d., k. 118.

47 Archiwum BU, sygn. 84, okólniki, k. 246. 
i wysokie, na co wskazują informacje o dość skromnych zamówieniach zrealizowanych z konta Towarzystwa. Potwierdzenie faktu, że nie dysponowało ono wielkimi środkami, znajdujemy też w prośbie Vrtela-Wierczyńskiego skierowanej do przewodniczącego Ćwiklińskiego o wyrażenie zgody na zapłacenie Bukowskiemu zaliczki za wykonywaną kopię obrazu. Napisał on dość ironicznie, że „konto Towarzystwa Przyjaciół Biblioteki wykazuje "poważne» (ca: 150 zł) kapitały" 48 .

Jak ocenić efekty działania Towarzystwa? Bez wątpienia były one zerowe, jeśli chodzi o poprawę sytuacji magazynowej, bo do wybuchu wojny, mimo wielokrotnego podkreślania takiej potrzeby, nie tylko nie wybudowano nowego gmachu, ale nawet nie rozpoczęto żadnych prac kosztorysowych czy planistycznych. We wspomnianym sprawozdaniu wieloletnim Vrtel-Wierczyński, pisząc o dużym znaczeniu darów, wydatnie pomnażających zbiory biblioteczne i wzbogacających je materiałami o znaczeniu historycznym oraz $\mathrm{z}$ aktualnego rynku księgarskiego, wymienił wiele różnych instytucji i towarzystw jako niezwykle zasłużonych w tej kwestii. Zakończył ten akapit zdaniem: „W pewnej mierze przyczyniło się w zakresie pomnażania zbiorów Towarzystwo Przyjaciół Biblioteki Uniwersyteckiej" ${ }^{49}$. Oględność tego zapisu można właściwie interpretować wyłącznie jako dyplomatyczne stwierdzenie, że efekty te nie były zbyt imponujące. Oczywiście taka ocena może dotyczyć tylko tych książek, które zostały oficjalnie zakupione ze środków zebranych przez Towarzystwo. Nie ma dokładnego ich spisu i liczbę zakupionych można szacować wyłącznie na podstawie danych zawartych w sprawozdaniach na ok. 200 tytułów w ok. 250 woluminach. Nie była ona - jak widać - zbyt imponująca, ale w kontekście ówczesnych potrzeb Biblioteki zakupy te stanowiły jednak odczuwalne wzbogacenie. Równocześnie w wykazach darczyńców odnajdujemy nazwiska osób, które były członkami tegoż Towarzystwa i osobiście przekazywały tytuły zasilające zasób Biblioteki ${ }^{50}$. Niestety nie zawsze podawano konkretne dane liczbowe,

${ }^{48}$ Ibidem, list Stefana Vrtela-Wierczyńskiego z 25.04.1933, k. 115.

49 Sprawozdanie Dyrekcji Biblioteki Uniwersyteckiej w Poznaniu za rok akademicki 1936/37 (od 1 września 1936 do 31 sierpnia 1937) oraz Ogólny Pogląd na działalność Biblioteki Uniwersyteckiej w Poznaniu w latach 1927-1937, Poznań 1937, rkps BU 104887 IV, s. 99.

50 Przykładowo w Kronice Uniwersytetu Poznańskiego za rok szkolny 1935/36 za rektoratu prof. dr. Stanisława Rungego (Poznań 1937, s. 296) wśród darczyńców największej liczby książek z nazwiska wymieniono prof. Tadeusza Grabowskiego, a Sprawozdanie Dyrekcji Biblioteki Uniwersyteckiej w Poznaniu za rok akademicki 1936/37 (od 1 września 1936 do 31 sierpnia 1937) oraz Ogólny Pogląd na działalność Biblioteki Uniwersyteckiej w Poznaniu w latach 1927-1937, Poznań 1937, rkps 
czasem zapisywano tylko nazwisko, niekiedy uzupełnione adnotacją o przekazaniu np. mapy czy rękopisu w przypadku prof. Erzepkiego, czy o fakcie stałego wspomagania Biblioteki, jak to uczyniono przy nazwisku prof. Grabowskiego. Mimo wszystko na podstawie analizy sprawozdań i zapisów w księgach darów ${ }^{51}$ można wyliczyć, że sami członkowie zarządu przekazali prywatnie co najmniej 1346 woluminów, w czym największą aktywność wykazali przewodniczący Ćwikliński (737 woluminów), Vrtel-Wierczyński (308), Kawecka (203) oraz Grabowski (85). Inni zidentyfikowani członkowie Towarzystwa byli nie mniej aktywni, ponieważ można im przypisać ofiarowanie łącznie przeszło 1500 woluminów. W tej grupie prym wiedli: Chrzanowski (617), Rutkowski (332), Erzepki (197, w tym 35 rękopisów i 16 starych druków), Winiewicz (134) oraz Wrzosek (100). Należy także przykładowo wskazać, że - zapewne zgodnie z wyrażoną wolą - po śmierci Denizota rodzina przekazała 1601 woluminów, a z księgozbioru Meissnera do Biblioteki trafiło 1931 woluminów. W każdym z tych przypadków przekazywane materiały stanowiły wartościowe, tematycznie profilowane kolekcje czy zespoły.

Należy jednak raz jeszcze podkreślić, że rolą członków Towarzystwa było propagowanie w miejscach pracy, w kręgach znajomych i przyjaciół idei wspomagania Biblioteki, czemu wskazany poprzednio przykład własny bezsprzecznie służył. I w tym zakresie zapewne odgrywali oni niemałą rolę, inspirując przykładem czy też zachęcając, mobilizując do podejmowania tego typu inicjatyw osoby prywatne, a może wręcz naciskając czy zapraszając do ofiarowywania książek instytucje państwowe. W wykazach ówczesnych darczyńców znajdujemy wiele nazwisk znanych poznańskich pracowników nauki, w większości, choć nie tylko, związanych z uniwersytetem. Przykładowo 7 lipca 1934 roku prof. Antoni Peretiatkowicz przekazał 326 tomów z prawa i filozofii, dr Kazimierz Krotoski 1 maja 1936 roku - 709, a wdowa po śp. prof. Stanisławie Dobrzyckim 139 woluminów. Ksiądz prof. Szczęsny Dettloff dwukrotnie obdarował Bibliotekę - łącznie przekazał 163 woluminy. Wielokrotnie w spisach pojawiają się nazwiska np. prof. Jana Rafalskiego, prof. Stanisława Pawłowskiego, prof. Józefa Paczkowskiego, dyrektora Muzeum Wielkopolskiego dr. Jerzego Kollera czy dr. Andrzeja Wojtkowskiego, którzy przekazywali mniejsze ilości materiałów. Ponieważ czynili to systematycznie, w sumie każda z tych osób ofiarowała powyżej

BU 104887 IV, s. 52-53 informuja, że w roku 1936/37 członkowie zarządu Ćwikliński i Chrzanowski przekazali odpowiednio 189 i 60 woluminów.

${ }^{51}$ Księga darów od 29.10.1927 do 31.11.1931, Archiwum BU, sygn. 2242; Księga darów od 2.01.1932 do 31.08.1836, Archiwum BU, sygn. 2243; Księga darów od 01.09.1936, Archiwum BU, sygn. 2245 


\section{Dary na rzecz Bibljoteki Uniwersyt.}

Dzięki ofiarności spoleczeństwa wielko. polskiego wzbogaciła się Biblioteka Univer. sytecka w Poznaniu o szereg nowych nabytków.

P. hr. August Cieszkowski z Wierzenicy zlożył w formie depozytu rekopis oica swego Augusta hr. Cieszkowskiego p. t. „Ojczo nasz" oraz, w formie daru, francuskie wydanie tego dziela.

P. ministrowa Wanda Korytowska z Po. znania ofiarowala do zbiorów Biblioteki 226 tomów treści historycznej, historyczno - literackiej i spoleczno - politycznej, oraz fascykuł rękopisów (aktów).

Centralne Tow. Gospodarcze w W. Księstwie Poznariskiem ziożyło w darze zbió dziel $z$ zakresu rolnictwa, gospodarstwa wiejskiego (hodowla zwierząt, pszczelnictwo etc), przyrodnictwa i ekonomji w ilości 1.566 tomów i 5.833 broszur.

P. Jan Popielecki z Poznania ofiarowa' 13 dzieł treści historycznej, społecznej, historyczno - literackiei i in.

P. Dr. Stanislaw Zieliniski z Poznania złożył w darze 42 dzieła przeważnie treści medycznej.

Il. 5. „Nowy Kurier" z 3.05.1929, nr 103 , s. 8

100 woluminów. Wspomniane instytucje, w tym m.in. zakłady czy katedry uczelni odnajdujemy na wielu stronach spisów i to nierzadko z darami rzędu kilku tysięcy woluminów.

Warto także przypomnieć, że 77 tomów z Wiednia w roku akademickim 1930/31 otrzymano - jak zapisano w sprawozdaniu - „dzięki interwencji” przewodniczącego Ćwiklińskiego ${ }^{52}$. Podobnie należy odczytywać podziękowania skierowane na jego ręce przez Vrtela-Wierczyńskiego za wystaranie się o „piękną subwencję” od Fabryki Drożdży w Luboniu. Nie podano jej wysokości, ale Wierczyński charakteryzuje ją jako „bardzo ważną w kasie Towarzystwa"53. Slad innego typu „zysków” odnajdujemy w notatce przygotowanej dla przewodniczącego 5 października 1931 roku, kiedy to w wykazie dezyderatów czekających na ewentualną realizację umieszczono m.in. książkę autorstwa Paula Waldemara

52 Sprawozdanie Dyrekcji Biblioteki Uniwersyteckiej w Poznaniu za rok akademicki 1930/31 (od 1 września 1930 do 31 sierpnia 1931), Poznań 1931, rkps BU 104887 IV, s. 22.

53 Archiwum BU, Towarzystwo Przyjaciół Biblioteki, sygn. 25, list S.Vrtela-Wierczyńskiego z 19.02.1934, k. 119. 
von Marienburga Die Sakramentsritter, wydaną we Wrocławiu w wydawnictwie Wahlstatt. Otóż dodano, że jeśli książka ta zostanie zakupiona, to nakładca zobowiązuje się do bezpłatnego przesyłania Bibliotece w przyszłości wszystkich swoich wydawnictw odnoszących się do historii i kultury Polski ${ }^{54}$. Przypomnijmy ponadto obietnice 50-procentowanego rabatu na dalsze tomy kupowane w Wilnie. Również kierownictwo Biblioteki, umieszczając od czasu do czasu na łamach miejscowej prasy informacje o darczyńcach i przekazanych przez nich darach (il. 5), z jednej strony zwracało uwagę na problem, z drugiej wpływało takimi podziękowaniami na ewentualne, podobne decyzje kolejnych osób.

Pozwala to stwierdzić, że dzięki staraniom, prośbom, dawanemu przykładowi uzyskiwano dla Biblioteki konkretne tytuły, propozycje atrakcyjnych warunków nabywania innych, a nade wszystko tworzono pozytywną aurę, która ułatwiała wspomaganie Biblioteki wieloma darami, także od osób i instytucji, które członkami Towarzystwa nie były i do których być może jego członkowie bezpośrednio - jak np. do wymienionych powyżej pracowników nauki - nie dotarli. Przypomnijmy, że w latach 1928/29-1937/38 Biblioteka Uniwersytecka przyjęła 74923 jednostki darów, co stanowiło przeszło $47 \%$ wszystkich wpływów, które przyczyniły się $\mathrm{w}$ dużym stopniu do zrealizowania wskazanych na początku zadań: repolonizacji zasobu i jego rozwoju, w tym wzbogacania wieloma cennymi zbiorami specjalnymi, których dotąd w Bibliotece brakowało $^{55}$. W tym dziele zapewne - być może pośrednio - Towarzystwo, jak i jego członkowie odegrali niepoślednią rolę ${ }^{56}$. Towarzystwo nie zostało nigdy formalnie rozwiązane. Jego działania przerwał wybuch II wojny światowej, po której zakończeniu w nowej sytuacji politycznej nie zostało reaktywowane.

${ }^{54}$ Ibidem, list Stefana Vrtela-Wierczyńskiego z 5.10.1931, k. 108-109.

55 Zob. m.in.: Stefana Vrtel-Wierczyński, Biblioteka Uniwersytecka w Poznaniu 1919-1929, Poznań 1929; S. Kubiak, Biblioteka Uniwersytetu im. Adama Mickiewicza w Poznaniu 1919-1966, Poznań 1967; M. Głowacka-Helak, Polonizacja księgozbioru Biblioteki Uniwersyteckiej w Poznaniu w latach 1919-1920, „Biblioteka” 2002, nr 6 (15), s. 87-96.

${ }^{56}$ Wiesława Turczynowicz, charakteryzując działalność Towarzystwa, oszacowała, że „w ciągu swej dziesięcioletniej działalności Towarzystwo spowodowało wzrost zbiorów Biblioteki o około 10 tys. wol.". Wskazała, że w tym pokaźną pozycję stanowiły dary, o których otrzymanie członkowie Towarzystwa aktywnie zabiegali. Jeśli tak szeroko (tj. ujmując pozyskane dzięki ich namowom czy wstawiennictwu dary) potraktujemy efekty działania Towarzystwa, to można przyjąć, że były one większe, niż wskazuje autorka. Por. W. Turczynowicz, Towarzystwo Przyjaciół Biblioteki Uniwersyteckiej w Poznaniu, w: Stownik polskich towarzystw naukowych, red. B. Sordylowa, t. 2, cz. 1, Wrocław 1990, s. 512-513. 


\section{Bibliografia}

Źródła

Archiwum BU, sygn. 20, Komisja Biblioteczna od 7.12.1919 do 25.06.1931.

Archiwum BU, sygn. 21, Komisja Biblioteczna od 14.10.1920 do 18.03.1932.

Archiwum BU, sygn. 25, Towarzystwo Przyjaciół Biblioteki.

Archiwum BU w Poznaniu, sygn. 35, Różne z lat 1904-1928.

Archiwum BU, sygn. 2242, Księga darów od 29.10.1927 do 31.11.1931.

Archiwum BU, sygn. 2243, Księga darów od 2.01.1932 do 31.08.1936.

Archiwum BU, sygn. 2245, Księga darów od 1.09.1936.

Sprawozdanie Dyrekcji Biblioteki Uniwersyteckiej w Poznaniu za rok akademic-

ki 1928/29 (od 1 września 1928 do 31 sierpnia 1929), Poznań 1929, rkps BU 104887 IV.

Sprawozdanie Dyrekcji Biblioteki Uniwersyteckiej w Poznaniu za rok akademic-

ki 1929/30 (od 1 września 1929 do 31 sierpnia 1930), Poznań 1930, rkps BU 104887 IV.

Sprawozdanie Dyrekcji Biblioteki Uniwersyteckiej w Poznaniu za rok akademic-

ki 1930/31 (od 1 września 1930 do 31 sierpnia 1931), Poznań 1931, rkps BU 104887 IV.

Sprawozdanie Dyrekcji Biblioteki Uniwersyteckiej w Poznaniu za rok akademic-

ki 1931/32 (od 1 września 1931 do 31 sierpnia 1932), Poznań 1932, rkps BU 104887 IV.

Sprawozdanie Dyrekcji Biblioteki Uniwersyteckiej w Poznaniu za rok akademic-

ki 1932/33 (od 1 września 1932 do 31 sierpnia 1933), Poznań 1933, rkps BU 104887 IV.

Sprawozdanie Dyrekcji Biblioteki Uniwersyteckiej w Poznaniu za rok akademicki 1933/34 (od 1 września 1933 do 31 sierpnia 1934), Poznań 1934, rkps BU 104887 IV.

Sprawozdanie Dyrekcji Biblioteki Uniwersyteckiej w Poznaniu za rok akademicki 1934/35 (od 1 września 1934 do 31 sierpnia 1935), Poznań 1935, rkps BU 104887 IV.

Sprawozdanie Dyrekcji Biblioteki Uniwersyteckiej w Poznaniu za rok akademicki 1935/36 (od 1 września 1935 do 31 sierpnia 1936), Poznań 1936, rkps BU 104887 IV.

Sprawozdanie Dyrekcji Biblioteki Uniwersyteckiej w Poznaniu za rok akademicki 1936/37 (od 1 września 1936 do 31 sierpnia 1937) oraz Ogólny Pogląd na działalność Biblioteki Uniwersyteckiej w Poznaniu w latach 1927-1937, Poznań 1937, rkps BU 104887 IV.

Sprawozdanie Dyrekcji Biblioteki Uniwersyteckiej w Poznaniu za rok akademicki 1937/38 (od 1 września 1937 do 31 sierpnia 1938), Poznań 1938, rkps BU 104887 IV.

Kronika Uniwersytetu Poznańskiego za rok szkolny 1927/28 za rektoratu prof. dr. Jana Grochmalickiego, Poznań 1928.

Kronika Uniwersytetu Poznańskiego za rok szkolny 1928/29 za rektoratu prof. dr. Edwarda Lubicz-Niezabitowskiego, Poznań 1930. 
Kronika Uniwersytetu Poznańskiego za rok szkolny 1931/32 za rektoratu prof. dr. Jana Sajdaka, Poznań 1933.

Kronika Uniwersytetu Poznańskiego za rok szkolny 1933/34 za rektoratu prof. dr. Stanisława Rungego, Poznań 1935.

Kronika Uniwersytetu Poznańskiego za rok szkolny 1935/36 za rektoratu prof. dr. Stanisława Rungego, Poznań 1937.

\title{
Literatura
}

Głowacka-Helak M., Polonizacja księgozbioru Biblioteki Uniwersyteckiej w Poznaniu w latach 1919-1920, „Biblioteka” 2002, nr 6 (15), s. 87-96.

Kubiak S., Biblioteka Uniwersytetu im. Adama Mickiewicza w Poznaniu 1919-1966, Poznań 1967.

Vrtel-Wierczyński S., Biblioteka Uniwersytecka w Poznaniu 1919-1929, Poznań 1929.

\section{ARTUR JAZDON}

\section{The Society of the Friends of the University Library in Poznań in the years 1929-1939}

\begin{abstract}
Aвstract. One of the key objectives of the University Library established based on the collection of the former Kaiser-Wilhelm-Bibliothek was to Polonise its collections and streamline them to support the newly established Polish University. However, the financial resources allocated for this particular purpose were not sufficient enough to fit the purpose and, what is more, due to the emerging crisis in the country's financial situation and the time of national stringency, were systematically decreased by the authorities. To make up for the situation an attempt was made to support the Library by obtaining acquisitions beyond current expenditure, i.e. by gifts, endowments, and bequests and, first of all, by the introduced deposit copy scheme. Moreover, since 1923 first attempt were made to set up the Society of Friends of the University Library that eventually was established in 1929. Its goal was to provide a platform for all those who were ready to support the library financially or otherwise. The Society included people from all walks of life and all social strata. The Society continued to lend financial and moral support to the library and was instrumental in organising the money for necessary library materials until the outbreak of WWII though on a lesser scale that it had been expected. Though the membership of the Society was not large, its members succeeded in lobbying for the library and thus in making the general public more aware of its problems, reaching decision-makers and private people. All this resulted in substantial donations to the library in the years 1929-1939, which contributed significantly to help cover the basic assignments required in the collection shaping process.
\end{abstract}

Key words: Poznań University, Poznań University Library, acquisition policy, promotion of books and readership. 
